\title{
Under-five mortality differentials in urban East Africa: a study of three capital cities
}

\author{
Gideon Rutaremwa \\ Department of Population Studies, Makerere University \\ grutaremwa@isae.mak.ac.ug
}

\begin{abstract}
Studies have suggested that on average the big cities of East Africa enjoy more favorable living conditions compared to peri-urban and rural areas of this region. The current study aimed at examining under-five mortality differentials in the capital cities of East Africa and to establish whether there are substantial differences in infant and child mortality estimates in Nairobi, Dar-es-Salaam and Kampala. Using data from population and housing censuses of East Africa during the 1990s, the study examines differentials in under-five mortality in Nairobi, Kampala and Dar-es-Salaam. Analyses using a count-data regression model focused on some of the issues relevant in understanding urban differences in under-five mortality in East Africa. The findings suggest substantial variations in under-five mortality risks, with Nairobi experiencing lower infant and child mortality risks than either Kampala or Dar-es-Salaam. The key recommendation made from this study is that programmes aimed at improving the living conditions of urban dwellers should be promoted and that any future studies should focus on the living conditions among the poor urban dwellers and how these conditions interface with the health of the population.
\end{abstract}

Keywords: Under-five mortality; differentials; urban; capital cities; East Africa

\section{Résumé}

Des études ont suggéré qu'en moyenne les grandes villes d'Afrique de l'est bénéficient des conditions de vie plus favorables par rapport à péri - zones urbaines et rurales de cette région.

L'étude en cours visant à examiner la vie des écarts de mortalité dans les capitales de l'Afrique de l'est et pour savoir si il y a des différences substantielles dans les nourrissons et les estimations de la mortalité infantile dans Nairobi, Dar - es Salaam et Kampala. Données à l'aide de la population et le logement des recensements de l'Afrique de l'est dans les années 1990, l'étude examine les écarts dans la vie mortalité à Nairobi, Kampala et Dar-es-Salaam. Analyse à l'aide d'un modèle de régression de comptage-données axé sur certaines des questions pertinentes dans la compréhension des différences urbains dans la vie de la mortalité en Afrique de l'est. Les conclusions suggèrent des variations importantes dans la vie des risques de mortalité, à Nairobi, rencontre de réduction des risques mortalité infantile et à Dar-es-Salaam ou à Kampala. T recommandation clé il est fabriquée à partir de cette étude est que les programmes visant à améliorer les conditions de vie des citadins devraient être encouragés et que toutes les futures études devraient se concentrer sur les conditions de vie parmi les citadins pauvres et comment ces conditions interfacent avec la santé de la population. 
Mots-clés : chez mortalité ; diffêrences ; urbain ; capital villes ; l'Afrique

\section{Introduction}

There is evidence to suggest that on average the big cities of East Africa enjoy more favorable living conditions than peri-urban areas and rural areas (Hanna and Hanna 198I; Brockerhoff and Brennan 1998). For example, numerous under-five mortality studies document rates that are higher in rural areas than in urban areas (Hobcraft, McDonald, and Rutstein 1984; United Nations 1985, 1991; Venkatacharya 1991; Cleland et al. 1992).

This paper discusses issues of under-five mortality differentials in the East African cities of Nairobi, Dar-esSalaam, and Kampala, drawing primarily on data collected from population and housing censuses in East Africa during the period 1990-2000 that covered socio-economic and demographic issues.

The study examines differentials in under-five mortality within the central cities of East Africa considering the following covariates: maternal education, marital status, source of water, and toilet facilities. The current study focuses on some of the issues relevant in understanding urban differences in under-five mortality in East Africa. In so doing, this study will examine whether there are substantial variations or similarities in under-five mortality and suggest some factors that are most related to underfive mortality in the central cities of East Africa.

\section{The capital cities of East Africa}

The cities of Nairobi, Kampala, and Dar-es-Salaam were founded during the second half of the nineteenth century. Although compared to other regions of Africa the percentage of population residing in urban areas in East Africa has remained the lowest, this region has, over the same period, sustained higher urban growth rates than other parts of Africa, averaging over $5 \%$ annually (United Nations 1993). Despite different historical backgrounds, the three cities share this similarity in annual population growth rate, converging to approximately $5 \%$ around 1990.

Geographical, historical and contemporary forces have shaped the current profiles of the cities of East Africa. Most cities of Africa (for example Kampala) initially developed from existing settlements; however, others (including Nairobi) were developed by the colonial administrators from scratch (O'Connor 1983). While colonial settlements in Dar-es-Salaam and Kampala were superimposed on and attached to earlier settlements, these cities currently predominantly reflect the development of European colonization rather than traditional settlement patterns.

The cities of East Africa, like several others in Africa, developed not as industrial centers, but to facilitate the extraction of commodities and the politico-administrative system on which this depended (Rakodi 1997). As hubs of capital accumulation and productive life, these cities have attracted large numbers of people from the hinter- 
lands, who migrate not only for employment but also to participate in the many urban functions and opportunities that these cities offer. The growing concern over rural-urban migration has often been alluded to in a negative context, particularly the development of slums and squatter settlements (Hanna and Hanna 198I; Mabogunje 1967). The argument here is that migration to cities breeds urban sprawl, which is associated with unemployment, and puts a strain on housing, health, and other urban services, often resulting not only in the development of a class of urban poor, but also far-reaching social, economic, health, and environmental consequences (Obudho 1997). However, the flow of people to urban areas should also be considered an inevitable process that has occurred in every developing society (Laurenti 1972). Concern over the various migration-related problems could encourage a more comprehensive view of the economic, social, health and other linkages, which should foster development of more rational urban policies. However, the extent to which such rational policies could be initiated and implemented is yet to be realized (Claquin 1991; Obudho 1997), particularly in East Africa.

These three capital cities of East Africa are not mere demographic agglomerations of population and growth (Magubane 2000), but they also provide us contexts within which the studies of demographic dynamics including under-five mortality derive. Characteristic of the cities of East Africa during the period prior to independence was the emergence of residential segregation. Equally, there was sex seg- regation manifested in the high sex ratio for these cities in Nairobi. Initially much of African urban growth was as unobtrusive as it was uncontrolled (Southall 1967; Obudho 1997). The capital cities of East Africa have become major centers of attraction to migrants seeking employment. In addition, the rates of urban growth, which had been accelerating prior to the main wave of countries attaining independence, have since slowed down but continue to be the highest on the continent (United Nations 1993). Despite evidence of negative health outcomes in pockets of poverty identified in these cities, the capital cities of East Africa in general have better health infrastructure and better health indicators than either the rural or the smaller urban centers. The aim of this paper therefore is to examine under-five mortality differentials in the capital cities of East Africa and to find out whether there are substantial differences in infant and child mortality estimates in Nairobi, Dar-es-Salaam, and Kampala.

\section{Related literature}

Several studies conducted suggest a strong association between under-five mortality and the level of urbanization (Rutaremwa, 1999, United Nations, 1991; Brockerhoff, 1990; Vidal and Ravanera, 1992). A majority of these studies often stress the fact that compared to rural areas; residence in urban areas is often associated with a reduction of infant and child mortality deaths (Brockerhoff and Hewett 2000,). Even mortality rates and prevalence of ill health are higher among groups of lower social standing in all contemporary Western countries (Preston and Taubman, 1994). However, the existing 
relationship between urbanization and under-five mortality may be far more complex than what we have known from several existing studies. Timaeus and Lush (1995) argue that the wider social and physical environment of the households influence the health of children in urban areas. They add that child health is not solely determined by disposable household income and the way it is spent, but also on accessibility to health care.

Two studies using Kenya data (Rutaremwa, 1999; Ewbank, et al.; 1986) did not find a definitive explanation for the high under-five mortality in urban areas of Kenya. Evidence from the 199I census data for urban northern Uganda (Rutaremwa, 1999) also suggests high under-five mortality in urban areas, where internal displacement of people through civil strife has for the past decade resulted in poor living conditions leading to diverstating health conditions among the general population. One major explanation for the high under-five mortality reported in research findings is failure by some researchers to control for internal migratory patterns in their analyses (Ewbank, et al. 1986, Brockerhoff, 1995).

Evidence of high mortality in urban environments is not uncommon in historical populations. Preston and Haines (199I) found that America at the turn of the century also witnessed higher mortality in the urban areas. They explain that urban precincts were often associated with unsanitary conditions and congestion. Improved knowledge of the etiology of infectious diseases and personal hygiene are credited to have been a source of child mortality decline between 1900 and 1930 in the United States (Preston and Ewbank, 1991). In this connection, educational attainment of parents is often singled out as the feature that is most predictive of the success in introducing healthenhancing techniques into the household.

Concerning urbanization trend, previous studies seem to agree on the fact that households who have recently migrated from rural areas tend to experience higher infant and child deaths compared to other urban households (Bicego and Ahmad, 1996; Brockerhoff, 1995). In a Senegalese study (Brockerhoff, 1989), migrant mortality disadvantages persisted even after controlling for socioeconomic and demographic factors. However, the risks of infant and child mortality were moderately after the migrants spent time in urban areas. Explanation for the latter phenomena points to the factors associated with the migration process, notably the structural assimilation of migrants into the urban community.

The relationship between migration and under-five mortality, within the context of urbanization is therefore not a direct one, and is likely to be a function of several factors. Migration research in sub-Saharan Africa suggests that adult migrants retain many of their norms, occupations and living arrangements (Hanna and Hanna, 1981; O'Connor, 1983 Illife, 1987). There is also evidence to suggest that these migrants are more likely to settle in slums and shanty towns where the basic household facilities essential for child health are unavailable (Brockerhoff, 1995). Furthermore, the physical process of moving exposes the 
migrant, particularly the young children to numerous hardships including new diseases, temporary residence in crowded dwellings and separation from additional care givers. All these and possibly other factors undermine the child's well being and may subject it to uncertainties particularly the contact with disease agents previously unknown to them (Prothero, 1977).

Another important issue to consider while examining infant and child mortality differentials in the cities of East Africa is the scourge of HIV/AIDS. Within the three cities examined in this paper, HIV has been identified as a serious health and socioeconomic issue. Evidence suggests that throughout East Africa adult urban residents perceive themselves to be at a greater risk of contracting HIV/AIDS compared to rural residents and this risk is even greater among those living in the major cities of this region. Recent Demographic and Health Surveys for the three countries (Republic of Kenya, 1998; Republic of Tanzania, 1996; Republic of Uganda, 1995) suggests that both HIV prevalence rates and history of STD infection in the years preceding the survey were highest in the urban areas. Although the principal mode of HIV transmission is considered to be heterosexual contact (70 percent), of particular concern is perinatal transmission from mother to child, which accounts for about 30 percent of babies born to HIV-positive mothers within this region. These infected children are at an even greater risk of dying in infancy or before they reach the age of five.

\section{Data}

Analyses in this paper address the issue of under-five mortality differentials for the three capital cities of East Africa. To assess these differences and similarities, I extract from the 1990 round of censuses (Kenya 1989, Tanzania 1988 and Uganda 1991), data for young women of ages 15-34 from Nairobi $(7,139)$, Dar-es-Salaam $(7,462)$, and Kampala $(20,055)$, who had borne at least one child by the time of the census. The choice of the 1990 censuses' data was based on comparability and access restrictions, especially for Kenya and Tanzania. The obvious shortcoming of such comparative study is lack of data collected at the same period. Nonetheless, under-five mortality in the three countries has remained fairly stable since the 1990 (PRB 2008), suggesting that analyses based on the 1990 round of censuses may still lead to valid conclusions and recommendations.

The 1990 round of censuses had two types of questionnaire: a short one with very few variables and a long one with more variables. The long one was administered on sample basis which varied between Uganda, Kenya and Tanzania. This explains why Nairobi with a bigger population than Kampala has fewer women in this analysis, and the same is true for Dar es Salaam. The inter-city differences observed in the number of women is due to sampling. These data contain specific variables that are important in the analysis of urban differentials in child mortality in the three cities of East Africa, including information on children ever born and surviving, educational status and marital status of the mother, as well as household-level variables such as type of toi- 
let facility and source of water. It should be noted that the selected age group has the best reporting on children ever born. Whereas some studies have indi- cated that the reporting in the age group 15-19 may be poor, it was not significantly different from other age groups within the range 15-34.

Table I Characteristics of respondents (only mothers aged I5-34)

\begin{tabular}{|c|c|c|c|}
\hline Variable & Nairobi & Dar-es-Salaam & Kampala \\
\hline \multicolumn{4}{|l|}{ Education } \\
\hline None & 8.6 & 21.5 & 6.9 \\
\hline Primary & 42.0 & 67.9 & 48.0 \\
\hline Secondary and above & 49.4 & 10.6 & 45.1 \\
\hline \multicolumn{4}{|l|}{ Marital status } \\
\hline Never married & 23.7 & 16.4 & 18.4 \\
\hline Previously married & 3.6 & 7.8 & 9.7 \\
\hline Currently married & 72.8 & 75.8 & 71.9 \\
\hline \multicolumn{4}{|l|}{ Age group } \\
\hline $15-19$ & 7.3 & 8.6 & 12.2 \\
\hline $20-24$ & 31.5 & 29.2 & 34.1 \\
\hline $25-29$ & 37.6 & 35.9 & 32.4 \\
\hline $30-34$ & 23.6 & 26.3 & 21.3 \\
\hline \multicolumn{4}{|l|}{ Source of water } \\
\hline Well & 1.9 & 18.6 & 48.0 \\
\hline Other source & 0.9 & 0.3 & 1.3 \\
\hline Pipe-borne & 97.2 & 81.1 & 50.7 \\
\hline \multicolumn{4}{|l|}{ Toilet facility } \\
\hline None & 1.8 & 2.0 & 1.9 \\
\hline Other facility & 37.8 & 84.8 & 84.1 \\
\hline Flush & 60.4 & 13.2 & 13.9 \\
\hline Total women & 7139 & 7462 & 20055 \\
\hline
\end{tabular}

Note: Other source of water and other type of toilet facility refer to all other categories than those indicated in Table I above.

Table I shows some selected characteristics of the respondents. There seem to be a number of differences and similarities in the respondent populations of the three cities included in the current study. Only a few salient features of the respondents' characteristics are examined in this section. The age pattern of women 15-34 is similar in each country with approximately 10 $\%$ of the respondents in the age-group 15-19; this proportion increases to at least $30 \%$ in the age groups $20-24$ and 25-29, and subsequently declines to slightly more than $20 \%$ in the age group 30-34. Age is important because it is closely related to child survival. Findings from research in developing countries suggest that births to older women are usually prone to higher mortality risks. This is also true of firstorder births that occur to very young mothers (Ewbank 1982, Rutstein 1992).

The marital status variable shows that overall almost three-quarters of the respondents from the three cities were in marital unions at the time of the censuses. The expected outcome is that women who are in marital relationships have some extra support from 
their husbands and are in a better position to provide for the health and nutritional needs of their children, resulting in higher survival of such children. Results in Table I show that Nairobi had slightly more mothers in the never married category than Dar-es-Salaam or Kampala. More significantly, marriage is early and almost universal among the population of East Africa, and this is reflected in the major urban areas of these countries.Educational level differences exist among the study populations from the three cities. Results in Table I suggest that Dar-es-Salaam had more mothers in the no education category than either Nairobi or Kampala. Furthermore, Dar-es-Salaam had almost two-thirds of the study population with only a primary education. The educational level attainment pattern for Nairobi and Kampala was largely similar, with an almost equal split between the proportion of mothers with a primary and a secondary or higher education.

The findings in Table I further show that whereas $97 \%$ of the mothers from Nairobi were residents of households with pipe-borne water sources, only about $8 \mathrm{I}$ and $5 \mathrm{I} \%$ of the mothers in Dar-es-Salaam and Kampala, respectively, had access to piped water. Approximately $60 \%$ of the study population from Nairobi resided in household with access to a flush toilet. However, an almost equal proportion of the study population from Dar-esSalaam and Kampala (84 \%) were households with other types of toilet facilities. The information in Table I suggests that Nairobi was better served with sanitary infrastructure than either Kampala or Dar-es-Salaam. Source of water and type of toilet facility, each with three dummy categories, are included in the analysis because not only are they proxies for standard of living of the households of the respondents but they are also indicators of environmental sanitation in these households. In addition, they show variation in the level of regional development, since we expect more-developed regions to have higher levels of infrastructure use. Among the basic services that could benefit child health are improvements in the quality of the drinking water and the provision of facilities for safe disposal of human excreta (Esrey, Feachem and Hughes 1985). The argument here is that respondents from households where pipe-borne water and flush toilet facilities are available enjoy a higher standard of living, and child survival among children in these households is higher.

\section{Methodology}

A poisson regression is used in this analysis. Poisson regression can fit a model of the number of occurrences (count) of an event, in this case the number of children dead. In this paper, the dependent variable $Y_{i}$ is the count of the number of children born alive who have subsequently died for mother $i$, $i=I, 2,3, \ldots, n$, where $n$ denotes the sample size. The count-datum $y_{i} s$ distribution depends on a set of exogenous variables, some of which are observed (the $x_{i}$ ) and some unobserved. Let $u_{i}$ represent unobserved variables and measurement errors on the data and let: 


$$
E\left\{Y_{i} \mid x_{i}, u_{i}\right\}=\lambda\left(x_{i}, \beta_{i}, u_{i}\right)=\lambda_{i}
$$

Where $E$ stands for the expectation operator, $\beta$ is the $\mathrm{k}$-dimensional parameter vector to be estimated and $u_{i}$ is the unobserved variables and measurement

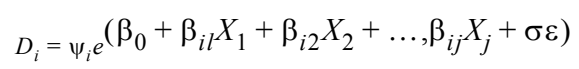

Where; $D_{i}$ is number of children dead, $\psi_{i}$ is the logarithm of the number of children born, $\beta$ is the vector parameters affecting under-five mortality levels while $X s$ are the covariates of interest. This final model adopted falls within the general framework of generalized linear models described, representing a special case of error or stochastic structure is Poisson. The link between the expectation of the dependent variable and the linear predictor is a logarithmic function and the linear predictor contains a known part or offset. This allows for the estimation of maximum likelihood, standard errors, and likelihood ratio goodnessof-fit chi-squares statistics.

Results from the negative binomial models are sometimes better expressed on a more convenient scale. All coefficients will be put on an exponential scale, thus interpretation of the parameters $(\beta)$ obtained from the negative binomial regression models will be in terms of incident rate ratios. The incident rate ratios are obtained by exponentiation of the regression coefficients, that is, $\exp [\beta]$. For ease of interpretation, the expression $100 *(\exp [\beta]-$ errors in the data. The form of the loglinear regression model specification is given as:

I) would tells us the percentage change in the incidence or risk of under-five mortality for each unit increase in the independent variable.

\section{Results}

According to Table 2, the trend in overall under-five mortality seems to characterize infant mortality estimates over the same period of time 1975 through 1986 averaging 86 under-five deaths per 1000 live births.

In Dar-es-Salaam, the under - five mortality rate was higher than the other two cities of Nairobi and Kampala. According to Table 2, it averaged 176 deaths per 1000 live births over the period 1974 through 1985. Under - five mortality rates in Dar-es-Salaam imply approximately twice the rates for Nairobi across all age groups of women. However, there seemed to be an increase in infant mortality levels after 1984.

In Kampala, the estimates of underfive mortality for the period 1976 to 1988 lie between the lowest Nairobi rates and the highest rates for Dar-esSalaam's highest rates. According to 
results in Table 2, under - five mortality for Kampala averaged 126 deaths per 1000 live births over the period 1976 to 1988. There were temporal variations in under-five mortality rates for Kampala; with minimum estimates recorded in 198 I and the highest estimates registered for 1988 .

Table 2 Trends in under-five mortality estimates for three East African cities

\begin{tabular}{|c|c|c|c|c|c|c|}
\hline \multirow[t]{2}{*}{ Age group } & \multicolumn{2}{|c|}{ Nairobi } & \multicolumn{2}{|c|}{ Dar-es-Salaam } & \multicolumn{2}{|c|}{ Kampala } \\
\hline & $\begin{array}{l}\text { Reference } \\
\text { period }\end{array}$ & 590 & $\begin{array}{l}\text { Reference } \\
\text { period }\end{array}$ & ${ }_{5} 9_{0}$ & $\begin{array}{c}\text { Reference } \\
\text { period }\end{array}$ & 590 \\
\hline $\begin{array}{l}20-24 \\
25-29 \\
30-34 \\
35-39 \\
40-44 \\
45-49\end{array}$ & $\begin{array}{l}1986 \\
1984 \\
1982 \\
1980 \\
1978 \\
1975\end{array}$ & $\begin{array}{l}0.100 \\
0.080 \\
0.106 \\
0.072 \\
0.082 \\
0.078\end{array}$ & $\begin{array}{l}1985 \\
1984 \\
1982 \\
1979 \\
1977 \\
1974\end{array}$ & $\begin{array}{l}0.186 \\
0.171 \\
0.170 \\
0.172 \\
0.185 \\
0.174\end{array}$ & $\begin{array}{l}1988 \\
1986 \\
1984 \\
1981 \\
1979 \\
1976\end{array}$ & $\begin{array}{l}0.134 \\
0.127 \\
0.123 \\
0.116 \\
0.131 \\
0.126\end{array}$ \\
\hline Mean for period & \multicolumn{2}{|c|}{$1975-1986=0.086$} & \multicolumn{2}{|c|}{$1974-1985=0.176$} & \multicolumn{2}{|c|}{$1976-1988=0.126$} \\
\hline
\end{tabular}

Note: The North Model of the Coale and Demeny (1983) Life Tables has been selected as standard

There seems to be close agreement in these estimates and the recent Demographic and Health Surveys for the three countries: Kenya, Tanzania and Uganda, in the trend of mortality, suggesting that indirect procedures of under-five mortality can work well in absence of vital registration. Generally, the estimates of under-five mortality obtained from the 1990 round of censuses show that Nairobi had lower rates than either Dar-as-Salaam or Kampala. The task in the next section is to examine whether these observed under-five mortality differences hold when individual level and household variables are controlled. The next section is also intended to investigate the variables that are related to under-five mortality in the East African cities.

Estimates of the incidence rate ratios of under-five mortality are presented in Tables 3, 4, 5 and 6. The first three tables present results based on individual city under-five mortality estimates processed separately, while results shown in Table 6 are from a combined data set for the three cities. The choice of the variables included in the models depended largely on the classification of the variable, whether a household or individual-level characteristic, and whether the variable is comparable in definition and classification across the three cities. Therefore, under-five mortality incidence rate ratios were computed using an identical set of dummy variables for each of the cities: Nairobi, Dar-es-Salaam, and Kampala.

In the first model (Tables 3, 4 and $5)$, only water, toilet facility, and age group of mother are examined. Results in Model I show that the incidence of under-five mortality was highest among children of mothers residing in household with no toilet facility than those in household with a flush toilet. The strength of this relationship is attenuated in Model 3, when education and marital status were added in the model. In fact, in the case of Nairobi the latter relationship ceases to be significant altogether. In general, results in Tables 3 
through 5 suggest that children born to mothers residing in households with a flush toilet had higher chances of surviving to the age of five than those of mothers residing in household using other or those who had no toilet facility.

Table 3 Estimated under-five mortality incidence rate ratios for Nairobi

\begin{tabular}{|c|c|c|c|}
\hline Variable/Category & Model I & Model 2 & Model 3 \\
\hline Education & & & \\
\hline None & - & ****2.766 & ****2.448 \\
\hline Primary & - & *****2.064 & **** | 875 \\
\hline Secondary and above $(\mathrm{RC})$ & - & - & - \\
\hline Marital status & & & \\
\hline Never married & - & 0.962 & 0.993 \\
\hline Previously married & - & $* 1.249$ & *** I.289 \\
\hline Currently married (RC) & - & - & - \\
\hline $\begin{array}{l}\text { Source of water } \\
\text { Well }\end{array}$ & 1.340 & - & 1.318 \\
\hline Other source & $\mathrm{I} .443$ & - & 1.314 \\
\hline Pipe-borne $(\mathrm{RC})$ & - & - & - \\
\hline $\begin{array}{l}\text { Toilet facility } \\
\text { None }\end{array}$ & $\begin{array}{l}\text { *** } \mid .525 \\
* * * * 1708\end{array}$ & - & $\begin{array}{l}\text { I. } 128 \\
* * * * 1416\end{array}$ \\
\hline $\begin{array}{l}\text { Other facility } \\
\text { Flush }(\mathrm{RC})\end{array}$ & - & - & - \\
\hline $\begin{array}{l}\text { Age-group } \\
\qquad 15-19(\mathrm{RC})\end{array}$ & 0.944 & - & $\overline{-}$ \\
\hline $\begin{array}{l}20-24 \\
25-29 \\
30-34\end{array}$ & $\begin{array}{c}* 0.75 \mathrm{I} \\
\mathrm{l} .034\end{array}$ & $\begin{array}{l}0.818 \\
1.034\end{array}$ & $\begin{array}{l}0.838 \\
1.088\end{array}$ \\
\hline $\begin{array}{l}\text { Log-likelihood } X^{2} \\
\text { Degrees of freedom } \\
\text { Number of observations }\end{array}$ & $\begin{array}{c}* * * * 102.6 \\
7 \\
7139\end{array}$ & $\begin{array}{c}* * * * 189.4 \\
7 \\
7139\end{array}$ & $\begin{array}{c}* * * 223.5 \\
\text { I I } \\
7139\end{array}$ \\
\hline
\end{tabular}

Estimates of the incidence of under-five mortality associated with source of water were not significant for either for Nairobi or Kampala (Tables 3 and 4, Model I), even after controlling for other variables in Model 3 . In the case of Nairobi, this is probably because a majority of the women (97\%) examined in this study were resident in a household with pipe-borne water. However, for Dar-es-Salaam, only one category of water source appears to be significant in the model, suggesting that pipe-borne water is associated with lesser odds of child deaths than well water.

Results for the mother's age variable were generally not significant in the regression models estimated for Nairobi and Dar-es-Salaam. The findings in Table 4, however, suggest significant differences in the incidence of under-five mortality for the various categories of mother's age except for the age group 20-24 in Kampala. In the three models estimated for Kampala, there is a direct relationship between age group of mother and the incidence of under-five mortality for her children. Results presented in Table 3 also show that in 
Kampala, children of mothers of the age group of mothers 15-19 experienced

the least incidence of under-five mortality than all the other age categories.

Table 4 Estimated under-five mortality incidence rate ratios for Kampala

\begin{tabular}{|c|c|c|c|}
\hline Variable/Category & Model I & Model 2 & Model 3 \\
\hline $\begin{array}{c}\text { Education } \\
\text { None } \\
\text { Primary } \\
\text { Secondary and above (RC) }\end{array}$ & $\begin{array}{l}- \\
-\end{array}$ & $\begin{array}{c}* * * 2.097 \\
* * * * 1.655 \\
-\end{array}$ & $\begin{array}{c}* * * 2.002 \\
* * * 1.589 \\
-\end{array}$ \\
\hline $\begin{array}{l}\text { Marital status } \\
\text { Never married } \\
\text { Previously married } \\
\text { Currently married (RC) }\end{array}$ & $\begin{array}{l}- \\
- \\
-\end{array}$ & $\begin{array}{c}* * * 1.153 \\
* * * 1.238 \\
-\end{array}$ & $\begin{array}{c}* * * 1.169 \\
* * * 1.226 \\
-\end{array}$ \\
\hline $\begin{array}{c}\text { Source of water } \\
\text { Well } \\
\text { Other source } \\
\text { Pipe-borne } \\
(R C)\end{array}$ & $\begin{array}{l}1.037 \\
0.900 \\
-\end{array}$ & $\begin{array}{l}- \\
-\end{array}$ & $\begin{array}{l}1.008 \\
0.902 \\
-\end{array}$ \\
\hline $\begin{array}{l}\text { Toilet facility } \\
\text { None } \\
\text { Other facility } \\
\text { Flush (RC) }\end{array}$ & $\begin{array}{l}* * * 1.928 \\
* * * * \mid .606 \\
-\end{array}$ & $\begin{array}{l}- \\
-\end{array}$ & $\begin{array}{c}* * * 1.559 \\
* * * 1.413 \\
-\end{array}$ \\
\hline Age-group & $\begin{array}{c}1.034 \\
* 1.134\end{array}$ & $\begin{array}{c}1.087 \\
* * * 1.193\end{array}$ & $\begin{array}{c}1.092 \\
* * * 1.207\end{array}$ \\
\hline $\begin{array}{l}20-24 \\
25-29 \\
30-34\end{array}$ & $\begin{array}{c}* * * * \mid .258 \\
-\end{array}$ & $\begin{array}{c}* * * * 1.293 \\
-\end{array}$ & $\begin{array}{c}* * * 1.322 \\
-\end{array}$ \\
\hline $\begin{array}{c}\text { I5- I9 (RC) } \\
\text { Log-likelihood } X^{2} \\
\text { Degrees of freedom } \\
\text { Number of observations }\end{array}$ & $\begin{array}{c}* * * \mid 38.5 \\
7 \\
20055\end{array}$ & $\begin{array}{c}* * * 4 \mid I .3 \\
7 \\
20055\end{array}$ & $\begin{array}{c}* * * 466.5 \\
\text { II } \\
20055\end{array}$ \\
\hline
\end{tabular}

Note: *** significant at $\mathrm{p}<0.0 \mathrm{I}$; ${ }^{* *}$ significant at $\mathrm{p}<0.05$; ${ }^{*}$ significant at $\mathrm{p}<0.10$; $(\mathrm{RC})=$ reference category

As expected, Model 2 (Tables 3, 4 and 5) show that the incidence of under-five mortality in the cities of East Africa were higher among children born to mothers with no education than to those with a secondary and higher schooling. In addition, attainment of primary schooling was associated with approximately twice the incidence of under-five deaths than when a mother had a secondary or higher education.
Controlling for source of water and type of toilet facility led to a slight reduction in under-five mortality incidence rate ratios associated with mother's education.

Table 3 shows that children of never-married mothers experienced under-five mortality risk not significantly different from that of currently married mothers. However, Model 2 shows that the incidence of under-five 
mortality was approximately $25 \%$ higher for children of previously married mothers than for currently mothers. This risk of under-five mortality associated with children of previously married mothers increased to about 30 $\%$ higher in Model 3 when education and marital status were controlled.

Table 5 Estimated under-five mortality incidence rate ratios for Dar-es-Salaam

\begin{tabular}{|c|c|c|c|}
\hline Variable/Category & Model I & Model 2 & Model 3 \\
\hline \multicolumn{4}{|l|}{ Education } \\
\hline None & - & ***2.489 & ****2.054 \\
\hline Primary & - & ***1.928 & ****1.654 \\
\hline Secondary and above (RC) & - & - & - \\
\hline \multicolumn{4}{|l|}{ Marital status } \\
\hline Never married & - & $* 1.119$ & $* 1.118$ \\
\hline Previously married & - & ***1.302 & **** I.300 \\
\hline Currently married (RC) & - & - & - \\
\hline \multicolumn{4}{|l|}{ Source of water } \\
\hline Well & *** 1.116 & - & *1.076 \\
\hline Other source & 0.444 & - & 0.399 \\
\hline Pipe-borne (RC) & - & - & - \\
\hline \multicolumn{4}{|l|}{ Toilet facility } \\
\hline $\begin{array}{c}\text { None } \\
\text { Othor }\end{array}$ & ***1.892 & - & ***1.599 \\
\hline Flush $(\mathrm{RC})$ & - & - & - \\
\hline \multicolumn{4}{|l|}{ Age-group } \\
\hline $20-24$ & 1.003 & 0.991 & 1.008 \\
\hline $25-29$ & 1.081 & 1.031 & 1.058 \\
\hline & & & \\
\hline \multicolumn{4}{|l|}{$15-19(\mathrm{RC})$} \\
\hline & **** | 0.4 & ****143.5 & ***** 98.5 \\
\hline Log-likelihood X² & 7 & 7 & 11 \\
\hline Degrees of freedom & 7462 & 7462 & 7462 \\
\hline Number of observations & & & \\
\hline
\end{tabular}

Note: *** Significant at $p<0.01$; ** significant at $p<0.05$; * significant at $p<0.10 ;(R C)=$ reference category

Unlike Nairobi (Table 3), the category of never-married mothers for Kampala and Dar-es-Salaam (Tables 4 and 5) were in the regression models. The findings in Models 2 and 3 suggest that for Kampala and Dar-es-Salaam, children of never married mothers had approximately 15 and $12 \%$ higher incidence of under-five mortality, respectively, than those of currently married women. In addition, the under-five mortality risks were highest for children of previously married mothers than those of currently married or never married mothers.

The incidence rate ratios from the combined data set appear in Table 6 (Models 4, 5, 6, and 7). In Model 4 only the dummies representing the cities 
and the continuous variable period were examined. These results suggest that the incidence of under-five mortality was significantly lower in Nairobi than in Kampala by about $40 \%$. The risk of under-five mortality was highest for Dar-es-Salaam than in either Nairobi or Kampala. Model 4 also shows that the incidence of under-five mortality was approximately $28 \%$ higher in Dar-es-Salaam than in Kampala.

Table 6 Estimated under-five mortality incidence rate ratios for Nairobi, Dar-es-Salaam, and Kampala (combined models)

\begin{tabular}{cccccc}
\hline & Variable/Category & Model 4 & Model 5 & Model 6 & Model 7 \\
\hline City & Nairobi & $* * * 0.631$ & $* * * 0.808$ & $* * * 0.635$ & $* * * 0.750$ \\
& Dar-es-Salaam & $* * * 1.277$ & $* * * 1.283$ & 1.037 & $* * 1.057$ \\
Kampala $_{(\mathrm{RC})}$ & - & - & - & -
\end{tabular}

Education

$$
\begin{gathered}
\text { None } \\
\text { Primary } \\
\text { Secondary and above }{ }_{(\mathrm{RC})}
\end{gathered}
$$

Marital status

Never married

Previously married

Currently married (RC)

Water source

$$
\begin{gathered}
\text { Well } \\
\text { Other } \\
\text { Pipe-borne } \\
\text { (RC) }
\end{gathered}
$$

Toilet facility

$$
\begin{aligned}
& \text { None } \\
& \text { Other }
\end{aligned}
$$

Flush (RC)

Age-group

$$
\begin{gathered}
20-24 \\
25-29 \\
30-34 \\
15-19_{(\mathrm{RC})}
\end{gathered}
$$

Log-likelihood $X^{2}$

Degrees of freedom

Number of observations

$\begin{array}{cccc}- & - & * * * 2.233 & * * * 2.058 \\ - & - & * * * 1.738 & * * * 1.637 \\ - & - & - & -\end{array}$

$\begin{array}{cccc}- & - & * * * 1.113 & * * * 1.131 \\ - & - & * * 1.256 & * * * 1.248 \\ - & - & - & -\end{array}$

$\begin{array}{cccc}- & * * 1.059 & - & 1.027 \\ - & 0.959 & - & 0.939 \\ - & - & - & -\end{array}$

$\begin{array}{cccc}- & * * * 2.028 & - & * * * 1.624 \\ - & * * * 1.689 & - & * * 1.457 \\ - & - & - & -\end{array}$

$\begin{array}{cccc}1.003 & 1.017 & 1.145 & 1.073 \\ 1.018 & 1.053 & * 1.093 & * * 1.111 \\ * * * 1.131 & * * * 1.191 & * * * 1.194 & * * * 1.228 \\ - & - & - & - \\ * * * 439.5 & * * * 730.1 & * * * 1133.2 & * * * 1269.3 \\ 5 & 9 & 9 & 13 \\ 34656 & 34656 & 34656 & 34656\end{array}$

Note: **** Significant at $\mathrm{p}<0.01$; ** significant at $\mathrm{p}<0.05$; * significant at $\mathrm{p}<0.10 ;(\mathrm{RC})=$ reference category.

Results in Model 4 show no signifi- those in the groups 20-24 and 25-29. cant differentials in the incidence of However, the findings suggest that the under-five mortality between children risk of under-five mortality was signifiof mothers in the age group 15-19 and cantly higher by approximately $13 \%$ 42 
among children of mothers aged 30-34 than those of mothers aged 15-19. After controlling for source of water and toilet facility in Model 5, the results show a similar pattern examined in Model 4, however, the incidence rate ratios associated with age group of mother slightly increased. Notably, the incidence rate ratios for women aged 30-34 increased by $5 \%$ from their values in Model 4.

Controlling for mother's education and marital status in Model 6 tends to alter the incidence rate ratios estimated for age group of mother. Models 6 and 7 show that the incidence of under-five death increases with age of mother. This finding in general accords with the expectation that children of older mothers have more exposure to the risk of mortality, and therefore experience higher incidences of death.

Results in Model 5 (Table 6) show that the direction and significance of the city incidence rate ratios were consistent with those in Model 4 examined earlier, suggesting that irrespective of source of water and type of toilet facility, under-five mortality odds are least in Nairobi and highest in Dar-es-Salaam, with Kampala in between. However, a look at the incidence rate ratios for Models 4 and 5 also suggests that source of water and type of toilet matter more in Nairobi than in Dar-esSalaam given that the incidence rate ratios change between the two models by $28 \%$ for Nairobi and by less than $1 \%$ in Dar-es-Salaam. Although the sign of the coefficients is maintained, these findings suggest that addition of mother's education and marital status in Models 6 and 7 alters the latter relationships further. Results in Table 6 also suggest that mother's marital status and educational level attainment explain a larger percentage of the difference between Nairobi and Kampala relative to Dar-es-Salaam. For example, comparison of results for Models 4 and 6 shows that the incidence rate ratios associated with residence in Nairobi as opposed to Kampala differ by approximately $1 \%$, while similar rates for Dares-Salaam show a difference of about $23 \%$. These results generally suggest that the relative importance of the predictor variables in the regression models varies in each of the East African cities.

Concerning the source of water variable, the findings in Model 5 show that only the well water category was significantly associated with higher risks of under-five mortality than pipe-borne water. Furthermore, Model 5 shows that children of mothers using well water had approximately $6 \%$ higher incidence of under-five mortality than those whose mothers used piped water. Other sources of water were not significant in the negative binomial regression models. In Model 7 when mother's education and marital status were included in the analyses, none of the water categories turned out to be significant.

Type of toilet facility was a very strong predictor of the risk of underfive mortality in the cities of East Africa. Results in Table 6 indicate that absence of a flush toilet facility in a household was associated with higher risks of child death. Comparison of results for Models 5 and 7 shows how addition of mother's education and her marital status in the model leads to attenuation of the effect of toilet facility in the regres- 
sion models.

Model 6 (Table 6) presents results for differentials of under-five mortality when we control for education and marital status. These results show that children born to mothers in Nairobi experienced lower incidence of underfive mortality than those born to mothers in Kampala and Dar-es-Salaam. The results in Model 6 also suggest that there was no significant difference in the risk of under-five mortality between Kampala and Dar-es-Salaam. However, results suggest a $6 \%$ higher incidence of under-five mortality in Dar-es-Salaam than in Kampala in the full model (Model 7) when water and toilet facilities are added in the equation.

The results in Models 6 and 7 generally confirm our expectation that there is an inverse relationship between the risk of under-five mortality and maternal education. This finding is consistent in the country-specific models examined in Tables 3 through 5. Concerning marital status, results in Table 6 show that children in the category of currently married mothers had the least incidence of under-five mortality than those of the never married and previously married mothers. With the exception of Nairobi, this result is consistent with the city-specific regression results in Tables 4 and 5 . As indicated earlier, this result is not surprising considering that on average the children of currently married mothers may have more resources and support from both parents at their disposal than children of women in other marital status categories. Therefore, children of the currently married mothers become more advantaged in terms of health, nutrition, and general welfare.

\section{Discussion}

Using negative binomial regression analysis procedures the study has explored this phenomenon and the factors that are most related to under-five mortality. The findings from these analyses underscore the fact that differences exist in under-five mortality levels in the three East African cities. Individual mothers' characteristics - age, education, marital status, and household living conditions (water and toilet facility) are related to infant and child mortality in all three cities. Perhaps the most interesting finding is that although $\mathrm{Nai}$ robi experienced lower under-five mortality than either Dar-es-Salaam or Kampala, the factors that are most related to infant and child mortality were similar in these central cities.

The usual explanation for geographic differentials in child mortality is differential socioeconomic development (Ewbank, Henin, and Kekovole 1986). In this study, even after controlling for other variables, education of mother remained significant in the regression equations. This study therefore reinforces the findings of several previous studies concerning the relationship between maternal education and child survival. The coefficients for education were highly significant and were the largest of all the variables included in the regression models. The results indicate an inverse relationship between maternal education and child mortality.

This relationship between maternal education and childhood mortality derives from a complex synergism. An educated mother is better equipped to identify and search for beneficial health behaviors that enhance the health of her 
children. Such practices as the use of modern health care facilities for prevention and treatment of child ailments are only examples. Moreover, an educated mother often has access to employment outside the home and is thus in a position to contribute to family financial resources (Schultz 1984). Education of mother operates through creation of aspirations for upward mobility, promotion of husband-wife communication on child survival issues, and facilitating acquisition of information related to proper planning for the family. The current study therefore corroborates many previous studies that have reached a conclusion that maternal education is inversely related to the under-five mortality. In terms of programs to reduce under-five mortality, any program that expands educational level attainment of mothers to at least a secondary level, coupled with sanitation education, should reduce the high under-five mortality in the cities of East Africa.

Type of toilet facility emerged as a highly significant predictor of the risks of child deaths for all the cities of East Africa. However, for all the study populations in the three cities, there seems to be less difference between having any other type of toilet facility and having none at all. The major difference appears to be one between the latter two categories and having a flush toilet facility. It appears that what is going on is not a mere test of difference in environmental sanitation per se, but also a difference in socioeconomic status and standard of living. Mothers who reside in households with a flush toilet facility belong to a higher social class and perhaps have a higher income; they may have adequate care to purchase health resources for their families. Source of water does not appear to be important in the regression models of the three cities. Whereas this may be a problem with data quality, it may also be true that source of water per se is not correlated with child deaths, so much as the way the water is handled and treated before it is eventually consumed.

Results with regard to marital status generally suggest that children of currently married mothers had lower risks of infant and child mortality; this relationship was generally true except for Nairobi where this category was not significant. The number of children surviving may not be an absolute, but rather dependent on many goals that parents pursue. Implicit in this is the fact that the risks of dying for children are dependent on the amount of resources parents allocate to the purchase of health care for their children (Scrimshaw 1978). Children of currently married mothers likely have more resources on average in terms of food and medication relative to children of mothers in other categories.

\section{Conclusion}

The findings from these analyses underscore the fact that differences exist in under-five mortality levels in the three East African cities. Individual mothers' characteristics - age, education, marital status, and household living conditions (water and toilet facility) - were related to infant and child mortality in all three cities. Perhaps the most interesting finding was that although Nairobi experienced lower under-five mortality than either Dar-es-Salaam or Kampala, the factors that were most related to infant 
and child mortality were similar in the three cities. Finally the key recommendation emerging from this study is that programmes aimed at improving the living conditions of urban dwellers should be promoted by the urban authorities in the region. Future studies should address especially the living conditions in poor-class neighborhoods in these cities, with view of informing policy on issues relating the health of the poor urban population that is fast and constantly growing.

\section{Acknowledgement}

This research was in part supported by a grant from NIH/NIA (ROI AG23I7 0I). Portions of this article are presented in my Ph.D dissertation in Demography entitled : "Infant and child mortality differentials in East Africa (2002)". The original work benefited greatly from helpful comments and supervision provided by Professors Tukufu Zuberi, Etienne van de Walle (R.I.P.) and Douglas Ewbank of the University of Pennsylvania Population Studies Center.

\section{References}

Bicego, G., and O. B. Ahmad. 1996. Infant and child mortality. Demographic and Health Surveys Comparative Studies no. 20.

Brockerhoff, M. 1990. Rural-to-urban migration and child survival in Senegal. Demography, vol. 27, 60I-6I6.

Brockerhoff, M. 1995 'Child Survival in Big Cities: The Disadvantages of Migrants', Social Science and Medicine.

Brockerhoff M, Brennan E. 1998. The poverty of cities in developing coun- tries. Population and Develop-ment Review. 24(I)

Brockerhoff, M. and P. Hewett. (2000): "Inequality of child mortality among ethnic groups in sub-Saharan Africa". Bulletin of the World Health Organization; 78(I).Claeson, C.F. and B. Egero. 1972. Migration and urban population: A demographic analysis of population census data for Tanzania. Research Notes No II:2. Bureau of Resource Assessment and Land Use Planning, University of Dar-es-Salaam.

Claquin, P. 1991. Urban expanded program on immunization (EPI). Arlington, VA: John Snow, Inc. and Washington, DC: U.S. Agency for International Development. Bureau for Science and Technology, Office of Health.

Cleland, J., G. Bicego, and G. Fegan. 1992. Socioeconomic inequalities in childhood mortality: The 1970s to the 1980s. Health Transition Review 2: $1-18$

Esrey, S.A., Feachem, RG, Hughes, JM. 1985. Interventions for the control of diarrhoeal diseases among young children: improving water supplies and excreta disposal facilities. Bulletin of the World Health Organization. 63: 757-72.

Ewbank, D.C. 1982. The sources of errors in Brass' method for estimating child survival: the case of Bangladesh. Population Studies 36:459-474.

Ewbank, D. C. and S.H. Preston. 1990. Personal health behavior and the decline in infant and child mortality: The United States, 1900-1930. In J. C. Caldwell et al. (editors), What we know about health transition: the cultural, social and behavioural 
determinants of health, Series No. 2 (Vol. I): pp II6-I49

Ewbank, D.C., R. Henin, and J. Kekovole. 1986. An Integration of Demographic and Epidemiologic Research on Mortality in Kenya, Determinants of Mortality Change and Differentials in Developing Countries: The Five-Country Study Project. New York: United Nations.

Hanna, W.J. and J.L. Hanna. 198I. Urban Dynamics in Black Africa. Second Revised Edition. New York: Aldine Publishing Company.

Harrison, P. 1982. Inside the Third World. Harmondsworth, UK: Penguin.

Henin, R. and B. Egero. 1972. The 1967 population census of Tanzania: A demographic analysis. Research Paper No 19. Bureau of Resource Assessment and Land Use Planning, University of Dar-es-Salaam.

Hobcraft, J.N., W. McDonald, and S.O. Rutstein. 1984. Socio-economic factors in infant and child mortality: A cross-national comparison. Popu-lation Studies 38: 193-223

lliffe, J. 1987. The African Poor: A History. African Studies Series 58. Cambridge: Cambridge University Press.

Laurenti, L. 1972. Urbanization in Kenya: Urbanization trends and prospects. Working Papers on the International Urbanization Survey. New York: The Ford Foundation.

Mabogunje, A.L. 1967. The morphology of Ibadan. in P.C. Lloyd, A.L. Mabogunje, and B. Awe (eds.), The City of Ibadan: A Symposium on its Structure and Development. London: Cambridge University Press.

Magubane, B.M. 2000. African Sociology:
Towards a Critical Perspective. The Collected Essays of Bernard Makhosezwe Magubane. Trenton, NJ: African World Press.

Obudho, R.A. 1997. Nairobi: National capital and regional hub. In $\mathrm{C}$. Rakodi (editors), The Urban Challenge in Africa: Growth and Man-agement of its Large Cities. New York: United Nations University Press.

O'Connor, A. 1983. The African City. New York: Africana Publishing Company.

Population Reference Bureau 2008. World Population Data Sheet.

Preston, S.H. and P. Taubman. 1994. A Socioeconomic Differences in Adult Mortality and Health Status. In Martin, L. and S.H. Preston, eds. Demography of Aging. Washington, DC: National Academy Press,

Preston, Samuel $H$. and Michael $R$. Haines. 199I. Fatal Years: Child Mortality in Late Nineteenth-century America. Princeton: Princeton University Press.

Prothero, M. 1977. "Disease and Mobility: A Neglected Factor in Epidemiology," International Journal of Epidemiology 6(3)

Rakodi, C. 1997. Global forces, urban change and urban management in Africa. In C. Rakodi. (ed.), The Urban Challenge in Africa: Growth and Management of its Large Cities. New York: United Nations University Press.

Republic of Kenya. 1989. Kenya Demographic and Health Survey, 1989. Nairobi: National Council for Population and Development, Central Bureau of Statistics, Office of the Vice President, and Ministry of Planning and National Development. 
. 1999. Kenya Demographic

and Health Survey, 1998. Nairobi: National Council for Population and Development, Central Bureau of Statistics, Office of the Vice President, and Ministry of Planning and National Development; and Calverton, MD: Macro International Inc. 2000. Kenya Demographic and Health Survey, 2000. Nairobi: National Council for Population and Development, Central Bureau of Statistics, Office of the Vice President, and Ministry of Planning and National Development.

Republic of Tanzania. 1982. Tanzania 1978 Population Census: A Summary of Selected Statistics. Volume IV, Dares-Salaam: Bureau of Statistics, Ministry of Planning and Economic Affairs.

.1989. 1988 Population

Census: Preliminary Report. Dar-esSalaam: Bureau of Statistics, Ministry of Finance, Economic Affairs and Planning.

- 1997. Tanzania Demographic and Health Survey, 1996. Bureau of Statistics, Ministry of Finance and Economic Affairs and Planning (Tanzania) and Calverton, MD: Macro International Inc.

Republic of Uganda. 1992. The 1991 Population and Housing Census: District Summary Series, Kampala: Statistics Department and Entebbe: Ministry of Finance and Economic Planning.

1996. Uganda Demographic and Health Survey, 1995. Calverton, MD: Statistics Department, Ministry of Finance and Economic Planning, and Macro International Inc.
Rutaremwa, G. 1999. Regional Differences in Infant and Child Mortality: A Comparative Study of Kenya and Uganda. ACAP Working Paper No 10. July 1999. The African Census Analysis Project (ACAP), Population Studies Center, University of Pennsylvania, Philadelphia, Pennsylvania.

Rutstein, S.O. 1992. Levels, trends and differentials in infant and child mortality in less developed countries. In K. Hill (editors). Child Health Priorities for the 1990s: Report of Seminar held June 20-22, 1991 at Johns Hopkins University School of Hygiene and Public Health. Baltimore, MD: Johns Hopkins.

Schultz, T.P. 1984. Studying the impact of household economic and community variables on child mortality. Population and Development Review, Supplement to volume 10: 215-235.

Scrimshaw, N. 1978. Nutrition and the Health of Nations. Occasional Paper No. 2, Vol. I. Chapel Hill, NC: The Institute of Nutrition.

Southall, A. 1967. Kampala-Mengo. In H. Miner, (ed.), The City in Modern Africa. New York: Frederick A. Praeger.

Timæus, I.M. and Lush, L. 1995. Intraurban differentials in child health. Health Transition Review, United Nations. 1993. World urbanization prospects: the 1992 revision. United Nations Department of Economic and Social Affairs and Policy analysis. New York

Developing Countries: Socioeconomic Differentials, Trends and Implications. Department of Economic and Social Development. United Nations, New York, Sales No. E.9I.XIII.I3. 
, 1985. Socioeconomic Differentials Child Mortality in Developing Countries. Department of Economic and Social Development. United Nations, New York, Sales No. E.85.XIII.7.

Venkatacharya, K.V. 199I. Socioeconomic differentials in infant and child mortality: Kenya case study. In Department of International Economic and Social Affairs, Child Mor- tality in Developing Countries: Socioeconomic Differentials, Trends and Implications. New York: United Nations.

Vidal, D. E.; Ravanera, Z. Altitude and urbanization: their influence on infant and child mortality in Bolivia. Population Studies Centre Discussion Paper, No. 92-9, ISBN 0-77|4-I40I3. May 1992. 